\title{
Endogenous GLP-1 as a key self-defense molecule against lipotoxicity in pancreatic islets
}

\author{
CHENGHU HUANG, LI YUAN and SHUYI CAO \\ Department of Endocrinology, Union Hospital, Tongji Medical College, \\ Huazhong University of Science and Technology, Wuhan, Hubei 430022, P.R. China
}

Received January 29, 2015; Accepted May 7, 2015

DOI: 10.3892/ijmm.2015.2207

\begin{abstract}
The number of pro- $\alpha$ cells is known to increase in response to $\beta$ cell injury and these cells then generate glucagon-like peptide-1 (GLP-1), thus attenuating the development of diabetes. The aim of the present study was to further examine the role and the mechanisms responsible for intra-islet GLP-1 production as a self-protective response against lipotoxicity. The levels of the key enzyme, prohormone convertase $1 / 3(\mathrm{PC1} / 3)$, as well as the synthesis and release of GLP-1 in models of lipotoxicity were measured. Furthermore, islet viability, apoptosis, oxidative stress and inflammation, as well as islet structure were assessed after altering GLP-1 receptor signaling. Both prolonged exposure to palmitate and a high-fat diet facilitated $\mathrm{PC} 1 / 3$ expression, as well as the synthesis and release of GLP-1 induced by $\beta$ cell injury and the generation of pro- $\alpha$ cells. Prolonged exposure to palmitate increased reactive oxygen species (ROS) production, and the antioxidant, $\mathrm{N}$-acetylcysteine (NAC), partially prevented the detrimental effects induced by palmitate on $\beta$ cells, resulting in decreased GLP-1 levels. Furthermore, the inhibition of GLP-1 receptor (GLP-1R) signaling by treatment with exendin-(9-39) further decreased cell viability, increased cell apoptosis and caused a stronger inhibition of the $\beta$ cell-specific transcription factor, pancreatic duodenal homeobox 1 (PDX1). Moreover, treatment with the GLP-1R agonist, liraglutide, normalized islet structure and function, resulting in a decrease in cell death and in the amelioration of $\beta$ cell marker expression. Importantly, liraglutide maintained the oxidative balance and decreased inflammatory factor and p65 expression. Overall, our data demonstrate that an increase in the number of pro- $\alpha$ cells and the activation of the intra-islet GLP-1 system comprise a self-
\end{abstract}

Correspondence to: Professor Li Yuan, Department of Endocrinology, Union Hospital, Tongji Medical College, Huazhong University of Science and Technology, 1277 Jiefang Avenue, Wuhan, Hubei 430022, P.R. China

E-mail: yuanli18cn@163.com

Key words: glucagon-like peptide-1, prohormone convertase 1/3, lipotoxicity, oxidative stress, inflammation, pancreatic islet defense mechanism for enhancing $\beta$ cell survival to combat lipid overload, which is in part mediated by oxidative stress and inflammation.

\section{Introduction}

Generally, the ectopic overaccumulation of lipids can trigger cellular dysregulation and functional tissue impairment, a process referred to as lipotoxicity (1). The investigation of the molecular mechanisms involved in lipotoxicity strongly indicates that excess lipids impair cell functions, leading to metabolically relevant cellular dysfunction, inflammation and oxidative stress $(2,3)$. The prolonged exposure of $\beta$ cells to increased levels of fatty acids, a major characteristic of lipotoxicity, elicits decreased insulin secretion, compromised insulin gene expression and $\beta$ cell apoptosis (2). Glucagon-like peptide-1 (GLP-1) is a gastrointestinal hormone primarily secreted by L cells in the intestine in response to food intake (4). Intriguingly, GLP-1 exhibits beneficial pleiotropic effects on $\beta$ cells by binding to a specific receptor (GLP-1R) and enhancing $\beta$ cell proliferation and survival $(5,6)$. GLP-1 has also been shown to protect pancreatic $\beta$ cells against lipotoxicityinduced apoptosis and promotes insulin gene expression (7-10). Moreover, the GLP-1R agonist, liraglutide, has been shown to suppress oxidative stress in rats with streptozotocin-induced diabetes (11). Importantly, intra-islet GLP-1 functions as a paracrine signal for damaged $\beta$ cells and is involved in protecting and regenerating them (12). In addition, the GLP-1R agonist, exendin-4, inhibits human islet inflammation (13).

Recently, interest in GLP-1 has intensified due to numerous important discoveries revealing that a functional GLP-1 system resides in $\alpha$ cells and is responsive to $\beta$ cell stress and injury $(14,15)$. Under normal conditions, pancreatic $\alpha$ cells secrete proglucagon, which is cleaved into glucagon by prohormone convertase 2 (PC2). However, under $\beta$ cell stress conditions, $\alpha$ cell hyperplasia, which is a hallmark of $\beta$ cell injury, develops (16). Notably, the dedifferentiation of hyperplastic $\alpha$ cells in adult islets seems to be preserved as an immature, pro- $\alpha$ phenotype attributable to the expression of prohormone convertase $1 / 3(\mathrm{PC} 1 / 3)(15)$, which is the key enzyme in the processing of proglucagon into GLP-1 peptides in $\alpha$ cells (17-20). Thus, we hypothesized that the activation of the intra-islet GLP-1 system may be a protective measure for enhancing cellular survival. 
We thus hypothesized that an intra-islet GLP-1 system may be the direct target of signals and self-preservation mechanisms that enhance $\beta$ cell survival against lipotoxicity, in which oxidative stress plays a critical role. Our findings suggest that an elevated number of immature pro- $\alpha$ cells and the generation of GLP-1 are an advantage to $\beta$ cells during conditions of high metabolic demand or stress, and that this 'self-defense' behavior facilitates $\beta$ cell survival by reshaping the oxidative balance and inhibiting inflammation.

\section{Materials and methods}

Animals. Male wild-type C57BL/6J mice were used for all the islet experiments. The mice were maintained under standard light conditions (12/12-h light/dark cycle) and were allowed free access to food and water. The male C57BL/6 mice and their food were purchased from Beijing HFK Bio-Technology Co., Ltd. (Beijing, China). The care and experimental treatment of the animals were approved by the Animal Research Committee of Tongji Medical College, Huazhong University of Science and Technology, Wuhan, China. Six-week-old mice, weighing $21 \pm 2 \mathrm{~g}$, were randomized into groups and fed either a high-fat diet (HFD; $20 \%$ protein, $20 \%$ carbohydrate and $60 \%$ fat), or a standard rodent chow diet [low-fat diet (LFD); 20\% protein, $70 \%$ carbohydrate and $10 \%$ fat]. After 4 weeks on the HFD or LFD, the mice were injected with liraglutide $(200 \mathrm{mg} / \mathrm{kg}$ body weight; Novo Nordisk, Princeton, NJ, USA) or a placebo [phosphate-buffered saline (PBS)] daily for 4 weeks. Body weight and food intake were measured weekly. To exclude the differences induced by food intake, all the mice fed the HFD were pair-fed. After the 8 weeks of feeding and drug administration, the mice were anesthetized with an intraperitoneal injection of pentobarbital sodium $(0.6 \mathrm{mg} / \mathrm{kg}$ body weight).

Metabolic measurements. For the measurement of fasting blood glucagon and insulin levels, the mice were fasted $6 \mathrm{~h}$. The insulin and glucagon concentrations were determined using the the insulin enzyme-linked immunosorbent assay (ELISA) kit (Millipore, Boston, MA, USA). The plasma GLP-1 concentrations were measured using an ELISA kit (Linco Research, St. Charles, MO, USA).

Islet isolation and cell culture. Non-diabetic mouse islets were isolated from the pancreata according to a previously described method (21). Specifically, the pancreas was perfused through the common bile duct with $1.5 \mathrm{mg} / \mathrm{ml}$ collagenase $\mathrm{P}$ (Roche Applied Science, Indianapolis, IN, USA), incubated at room temperature, and then further separated from the acinar tissue using a Histopaque 1077 gradient. The islets were isolated by hand and cultured for 24-72 $\mathrm{h}$ in RPMI-1640 medium in a $5 \% \mathrm{CO}_{2}$ incubator. Subsequently, the islets were examined according to the steps outlined below for the functional analysis.

Functional analysis. The non-diabetic islets were seeded into 24-well plates; 25 islets were added to each well. The palmitate solution was prepared as previously described (22). Following incubation in Krebs-Ringer Bicarbonate (KRB) buffer with $5.6 \mathrm{mmol} / \mathrm{l}$ glucose for $1 \mathrm{~h}$, the islets were incubated under the following conditions: $0.5 \% \mathrm{BSA}$ (as a control) or $0.5 \mathrm{mmol} / 1$ palmitate bound to $0.5 \%$ BSA for 24,48 or $72 \mathrm{~h}$.
We examined the role of oxidative stress in the detrimental effects of palmitate by treating the islets with the antioxidant, $\mathrm{N}$-acetylcysteine (NAC) (5 mmol/l; Sigma-Aldrich, St. Louis, MO, USA). Finally, to examine the bioactivity of islet-released GLP-1, experiments were performed in the absence or presence of the GLP-1R antagonist, exendin-(9-39) (0.5 $\mu \mathrm{mol} / \mathrm{l}$; SigmaAldrich) (14). The islets were pre-treated with $100 \mathrm{nmol} / \mathrm{l}$ liraglutide, $5 \mathrm{mmol} / 1 \mathrm{NAC}$ or $0.5 \mu \mathrm{mol} / 1$ exendin-(9-39) for $2 \mathrm{~h}$ followed by exposure to $0.5 \mathrm{mmol} / \mathrm{l}$ palmitate. The active GLP-1 content in the cell culture medium and cell lysates was measured using an ELISA kit (Linco Research).

MTT assay. After functional analysis, 3-(4,5-dimethylthiazol2-yl)-2,5-diphenyltetrazolium bromide (MTT) assay was used to determine the proportion of viable cells in the treated group compared to the control group, as previously described (23). The islets were incubated with $500 \mu \mathrm{g} / \mathrm{ml}$ MTT in RPMI-1640 medium for $3 \mathrm{~h}$ at $37^{\circ} \mathrm{C}$. At the end of the incubation period, the medium containing MTT was removed, and the islets or cells were dissolved in dimethyl sulfoxide (DMSO). The absorbance was measured at 540 and $690 \mathrm{~nm}$ using a microplate reader (Perkin Elmer EnSpire; Perkin Elmer, Waltham, MA, USA).

Apoptosis assay. DNA fragmentation activity in the islets was quantified using a Cell Death Detection ELISA Plus kit (Roche Diagnostics GmbH, Mannheim, Germany) according to the manufacturer's instructions. Following treatment, the cells were washed twice with PBS and incubated with lysis buffer for $20 \mathrm{~min}$ at room temperature. Following centrifugation to remove the nuclei and cellular debris, the supernatants were diluted 1:5 with lysis buffer, and each sample was analyzed using ELISA.

Mmeasurement of intracellular levels of reactive oxygen species (ROS). The quantification of intracellular ROS levels was carried out using the fluorescent probe, 2,7-dichlorofluorescein diacetate (DCFH-DA), as described in our previous study (24). The cells were washed twice with PBS and incubated in culture medium containing $20 \mu \mathrm{mol} / 1$ DCFH-DA (Beyotime Institute of Biotechnology, Beijing, China) for $20 \mathrm{~min}$ at $37^{\circ} \mathrm{C}$ in the dark. Subsequently, the cells were lysed with lysis buffer, and the carboxy-DCF fluorescence in the cell lysates was measured using a multimode microplate reader (Bio-Rad, Hercules, CA, USA) and excitation and emission wavelengths of 488 and $530 \mathrm{~nm}$, respectively.

Immunoblot analysis. The islets were seeded into 24-well plates; 50 islets were added to each well. Following treatment, the islets were washed with PBS prior to the addition of cell lysis buffer containing protease inhibitor cocktail and PhoshopStop tablets (Roche Applied Science). The primary antibodies used were PC1/3 (1:1,000; AB10553; Millipore) and pancreatic duodenal homeobox 1 (PDX1) (1:1,000; 5679; Cell Signaling Technology, Boston, MA, USA). An antibody against mouse $\beta$-actin (A1978) was obtained from Sigma-Aldrich. Densitometric analysis was performed using ImageJ software.

Immunodetection. After the mice were euthanized, and their pancreata were removed, the pancreatic tissue was harvested and fixed in $4 \%$ formaldehyde overnight and 
Table I. List of primers used for qPCR using SYBR-Green.

\begin{tabular}{|c|c|c|c|c|}
\hline Gene & Gene ID & Forward sequence $\left(5^{\prime} \rightarrow 3^{\prime}\right)$ & Reverse sequence $\left(5^{\prime} \rightarrow 3^{\prime}\right)$ & Length \\
\hline Nkx6.1 & NM_144955.2 & ACTTGGCAGGACCAGAGAG & GCGTGCTTCTTTCTCCACTT & 109 \\
\hline PDX1 & NM_008814.3 & TGAACTTGACCGAGAGACACAT & GGTCCCGCTACTACGTTTCTTA & 92 \\
\hline $\mathrm{PC} 1 / 3$ & NM_013628.2 & ACATGGGGAGAGAATCCTGTAGGCA & CATGGCCTTTGAAGGAGTTCCTTGT & 220 \\
\hline Insulin-1 & NM_008386.3 & GGACCCACAAGTGGAACAAC & GCTGGTAGAGGGAGCAAATG & 130 \\
\hline GLUT2 & NM_031197.2 & GCCAAGTAGGATGTGCCAAT & CCCTGGGTACTCTTCACCAA & 110 \\
\hline NOX4 & NM_015760.5 & ATTTGGATAGGCTCCAGGCAAAC & CACATGGGTATAAGCTTTGTGAGC & 155 \\
\hline p22phox & NM_001301284.1 & GGCACCATCAAGCAACCACC & CTCATCTGTCACTGGCATTGGG & 135 \\
\hline gp91phox & NM_007807.5 & TCCGTATTGTGGGAGACTGGACG & AATGGAGGCAAAGGGCGTGAC & 194 \\
\hline SOD2 & NM_013671.3 & CAGACCTGCCTTACGACTATGG & CTCGGTGGCGTTGAGATTGTT & 113 \\
\hline GPx-1 & NM_008160.6 & CCTCAAGTACGTCCGACCTG & CAATGTCGTTGCGGCACACC & 197 \\
\hline $\mathrm{IL}-1 \beta$ & NM_008361.3 & GCACACCCACCCTGCA & ACCGCTTTTCCATCTTCTTCTT & 69 \\
\hline IL-6 & NM_031168.1 & TCCAGAAACCGCTATGAAGTTC & CACCAGCATCAGTCCCAAGA & 73 \\
\hline TNF- $\alpha$ & NM_013693.3 & CTCCAGGCGGTGCCTATG & GGGCCATAGAACTGATGAGAGG & 149 \\
\hline 36B4 & NM_007475.5 & CAGCAAGTGGGAAGGTGTAATCC & CCCATTCTATCATCAACGGGTACAA & 75 \\
\hline
\end{tabular}

Length is indicate in bp. PDX1, pancreatic duodenal homeobox 1; PC1/3, prohormone convertase 1/3; GLUT2, glucose transporter 2; NOX4, NADPH oxidase 4; SOD2, superoxide dismutase 2; GPx-1, glutathione peroxidase 1; TNF- $\alpha$, tumor necrosis factor- $\alpha$; IL, interleukin.

stored in $70 \%$ ethanol. Fixed sections of pancreatic tissues were embedded in paraffin and cut into 5- $\mu$ m-thick sections. Paraffin-embedded sections were rehydrated, and antigen retrieval was performed using a PickCell pressure cooker. The primary antibodies used were guinea pig anti-insulin (1:150; ab7842; Abcam, Cambridge, UK), rabbit anti-PC1/3 (1:200; Millipore), rabbit anti-glucagon (1:200; 8233; Cell Signaling Technology) and rabbit anti-NF-kB p65 (1:200, ab16502; Abcam). The secondary antibodies were conjugated to Alexa Fluor 488 [1:200; AffiniPure goat anti-guinea pig $\operatorname{IgG}(\mathrm{H}+\mathrm{L})$; Cat. no. 106-545-003; Jackson ImmunoResearch Laboratories, West Grove, PA, USA] or DyLight 549 [1:200; goat antirabbit IgG (H+L); Cat. no. A23320; Abbkine Inc., Redlands, CA, USA]. The nuclear counterstain, 4'6'-diamidino-2-phenylindole (DAPI; Invitrogen, Carlsbad, CA, USA), was also used. All the digital images were acquired using a fluorescence microscope equipped with a DC200 digital camera (C-1/ TE200U; Nikon, Tokyo, Japan) and were subsequently analyzed using Image-Pro Plus version 5.0 image analysis software (Media Cybernetics, Rockville, MD, USA). The density threshold selection tool was used to select the pancreatic islet areas marked with insulin and glucagon, which was depicted as a percentage of the mean islet cross-sectional area (immuno-density), as previoulsy descibed (25).

Analyses of $m R N A$ expression by quantitative polymerase chain reaction ( $q P C R$ ). Total RNA from the isolated islets and mouse pancreatic tissue samples was extracted using TRIzol reagent (Invitrogen). First-strand cDNA synthesis was performed using a cDNA synthesis kit (Takara Shuzo Co., Ltd., Kyoto, Japan) and qPCR was performed using a LightCycler (Roche Diagnostics $\mathrm{GmbH}$ ). The primers used in this study are listed in Table I. The relative transcript levels were normalized to $36 \mathrm{~B} 4$ and calculated using the $2^{-\Delta \Delta C \mathrm{~T}}$ statistical method.
Statistical analysis. The results of the present study are expressed as the means \pm SEM values, and data were analyzed using the Student's t-test or one-way analysis of variance (ANOVA) followed by the Bonferroni post-hoc test. A value of $p<0.05$ was considered to indicate a statistically significant difference.

\section{Results}

Activation of the endogenous GLP-1 system in injured isolated islets. Following the incubation of the isolated mouse islets for 24,48 or $72 \mathrm{~h}$, treatment with $0.5 \mathrm{mmol} / \mathrm{l}$ palmitate for 24,48 and $72 \mathrm{~h}$ led to a significant decrease in islet viability and an increase in cell death in a time-dependent manner (Fig. 1A and B). Since the exposure of the cultured islets for $72 \mathrm{~h}$ was severely damaging, we focused on the effects of palmitate on $\beta$ cell-specific transcription factors after $48 \mathrm{~h}$ of treatment. Incubation with palmitate for $48 \mathrm{~h}$ did not significantly modify the mRNA expression of insulin (Fig. 1C). Nonetheless, both PDX1 mRNA and protein (Fig. 1D) levels decreased after $48 \mathrm{~h}$ of exposure to palmitate. Thus, prolonged exposure to palmitate induces injury to isolated islets.

Importantly, incubation of the cells with $0.5 \mathrm{mmol} / 1 \mathrm{palmi}-$ tate for 24,48 or $72 \mathrm{~h}$ markedly induced the release of GLP-1 into the culture medium by $3.15-, 6.55$ - and 5.62 -fold, respectively (Fig. 2A). Moreover, in line with the observations of the culture medium, the GLP-1 concentration in the cell lysates was elevated and showed an even greater increase (Fig. 2B). Nonetheless, the GLP-1 levels at $72 \mathrm{~h}$ in both the cell medium and the cell lysates were almost equivalent to those at $48 \mathrm{~h}$ and even showed a decreasing trend (Fig. 2A and B), which may be due to the severe serious injury induced by $72 \mathrm{~h}$ of exposure to palmitate (Fig. 1A and B; increased apoptosis and decreased cell viability). Following prolonged exposure to palmitate, the 

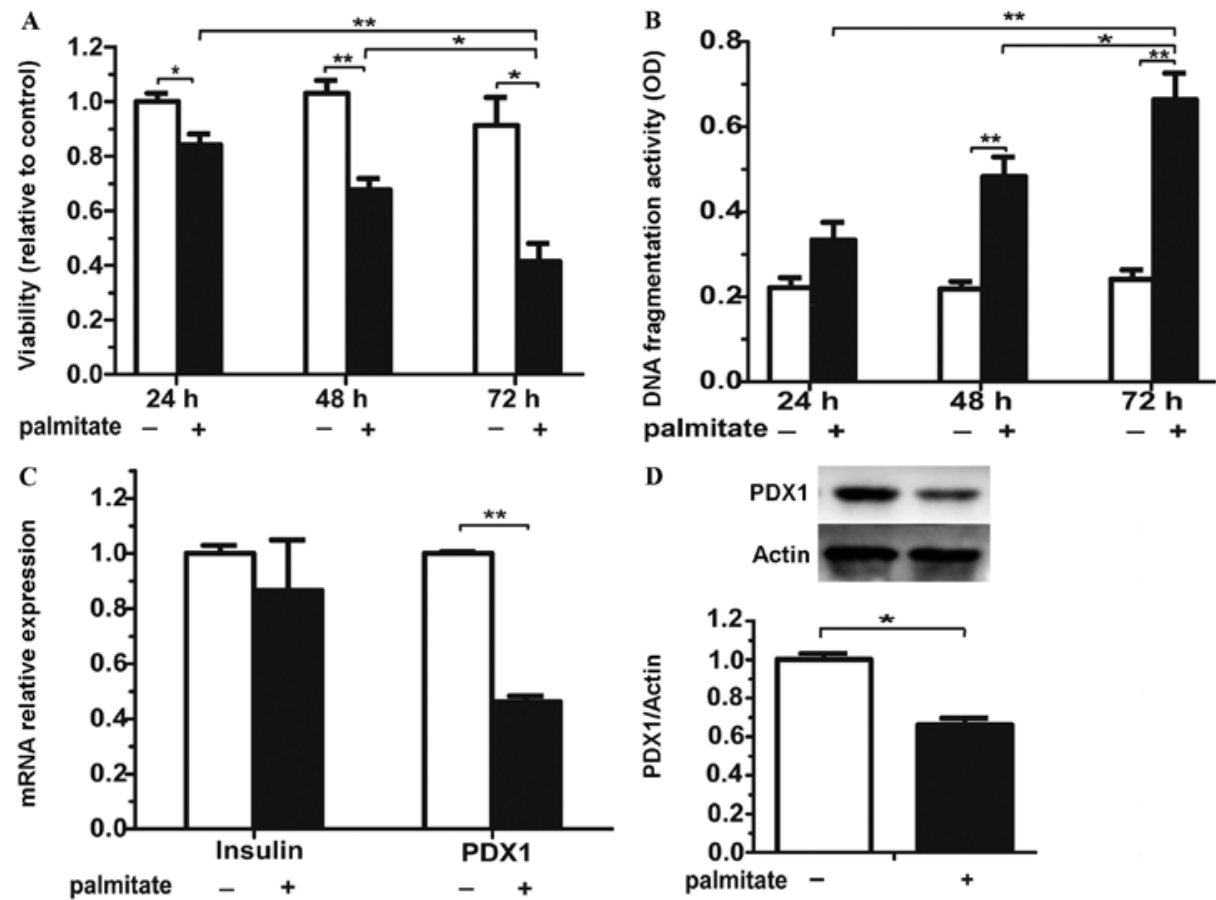

Figure 1. Palmitate induces injury to isolated mouse islets. Following incubation with $0.5 \mathrm{mmol} / \mathrm{l}$ palmitate for the indicated periods of time ( 24,48 and $72 \mathrm{~h}$ ), islet (A) viability and (B) apoptosis were analyzed by examining histone-associated DNA fragments and by MTT assay, respectively. Following incubation with $0.5 \mathrm{mmol} / 1$ palmitate for $48 \mathrm{~h},(\mathrm{C})$ the insulin mRNA and (D) pancreatic duodenal homeobox 1 (PDX1) mRNA and protein levels were determined by qPCR and immunoblot analysis, respectively. The relative transcript levels were normalized to those of $36 \mathrm{~B} 4 . \mathrm{n}=3$ separate islet preparations; ${ }^{*} \mathrm{p}<0.05 ;{ }^{* *} \mathrm{p}<0.01$.
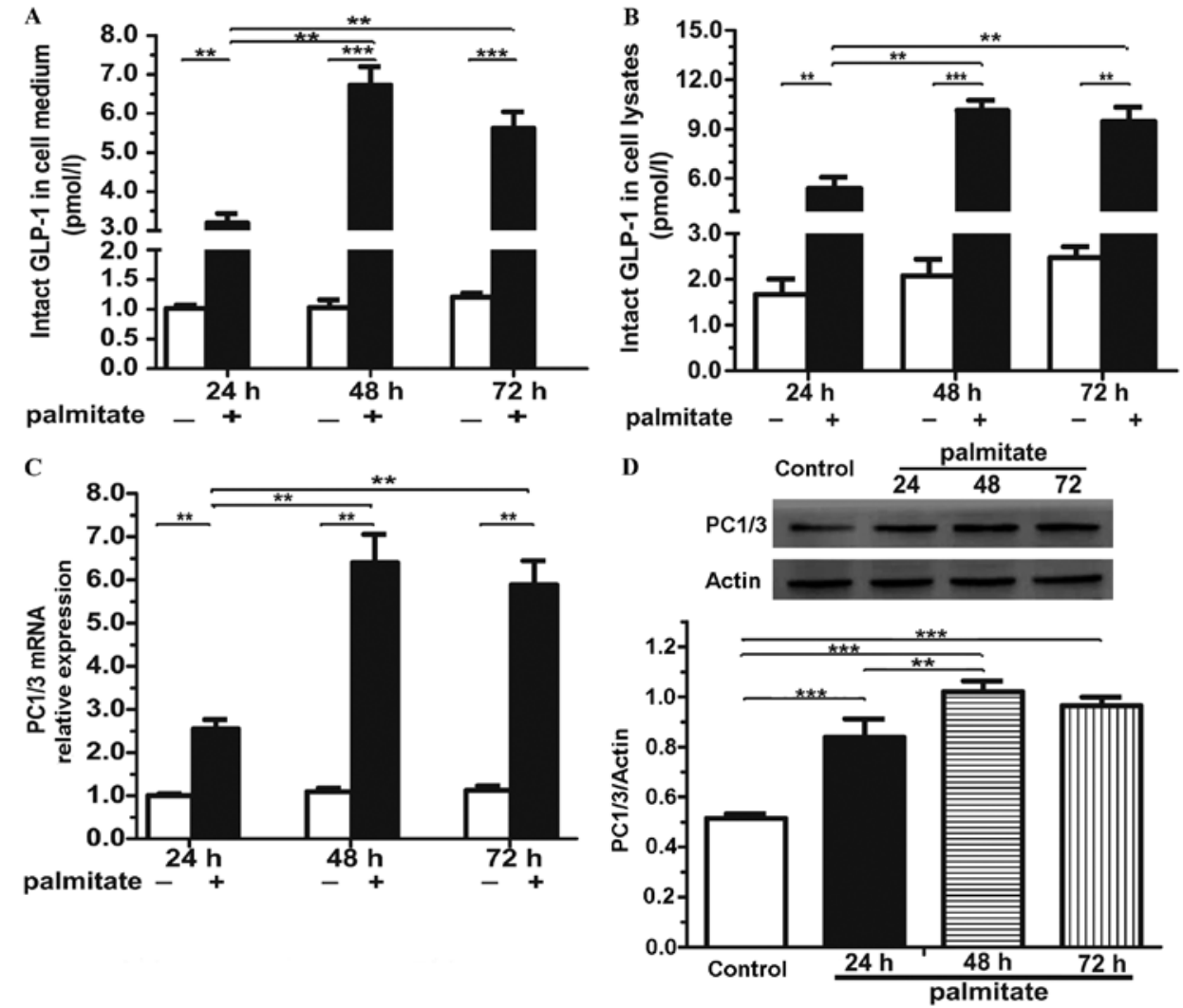

Figure 2. Prolonged exposure to palmitate induces the activation of the glucagon-like peptide-1 (GLP-1) system in isolated mouse islets. After the islet cells were incubated with $0.5 \mathrm{mmol} / \mathrm{l}$ palmitate for the indicated periods of time, the GLP-1 levels in the (A) cell medium and (B) lysates were determined by insulin enzyme-linked immunosorbent assay (ELISA), and (C) prohormone convertase 1/3 (PC1/3) mRNA expression in cell lysates was determined by qPCR and (D) the $\mathrm{PC} 1 / 3$ protein level was determined by immunoblot anlaysis. $\mathrm{n}=3$ separate islet preparations; ${ }^{* *} \mathrm{p}<0.01 ;{ }^{* * *} \mathrm{p}<0.001$. 

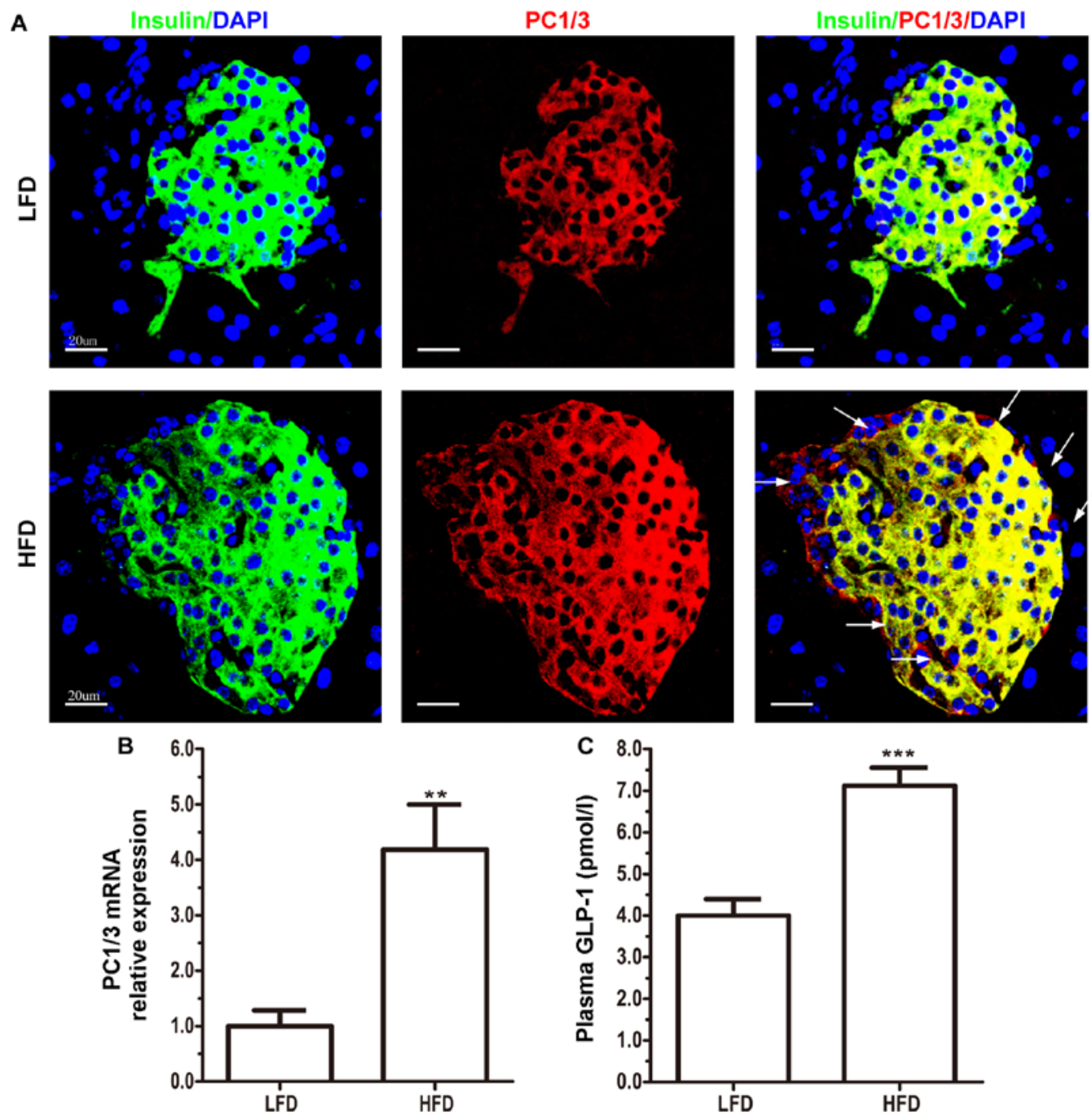

Figure 3. High-fat diet (HFD) induces intra-islet glucagon-like peptide-1 (GLP-1) system activation. (A) Representative images of immunofluorescence staining for insulin (green) and prohormone convertase 1/3 (PC1/3) (red) in the pancreatic islets of mice that were fed a low-fat diet (LFD) (n=6) or a HFD (n=7) for 8 weeks. The arrows indicate the insulin-negative and PC1/3-positive cells. (B) PC1/3 mRNA expression in the pancreata of mice from each group was detected by qPCR. (C) Plasma GLP-1 levels in the mice were detected by insulin enzyme-linked immunosorbent assay (ELISA). LFD compared with HFD; ${ }^{* *}$ p $<0.01 ;{ }^{* * * *}$ p $<0.001$.

mRNA (Fig. 2C) and protein levels (Fig. 2D) of PC1/3, the key enzyme of GLP-1 generation, also increased (48 h of exposure resulted in higher mRNA and protein levels than $72 \mathrm{~h}$ of exposure).

Elevated expression of GLP-1 in local pancreatic islets in vivo. After 8 weeks of being fed a HFD, PC1/3 protein expression in the HFD group markedly increased (Fig. 3A). Normally, insulin co-localizes with $\mathrm{PC} 1 / 3$ (Fig. 3A), which is known to cleave pro-insulin at the B-chain/C-peptide (26). However, we identified a few PC1/3-positive cells in the extracellular $\beta$ cell compartments (Fig. 3A). When the PC1/3-positive and insulinnegative $\alpha$ cells were quantified, an increased number of these cells (163 cells) was found in the HFD group $(n=7)$ compared with the LFD group ( $n=6 ; 48$ cells) in every 20 slices (data not shown). In addition to intestinal L cells, PC1/3, the key enzyme governing GLP-1 formation, is expressed in islet $\beta$ cells and pro- $\alpha$ cells (27), suggesting that the elevated number of $\mathrm{PC} 1 / 3$ positive and insulin-negative cells may be pro- $\alpha$ cells. Notably, in the HFD group, pancreatic PC1/3 mRNA expression was upregulated (Fig. 3B), and the plasma GLP-1 concentrations were increased compared with the LFD group (Fig. 3C), which was in accordance with the increase in $\mathrm{PC} 1 / 3$ protein expression (Fig. 3A) and may be the result of the activation of the intra-islet GLP-1 system. These results demonstrated that a HFD also induced the formation of pro- $\alpha$ cells and the release of GLP-1 through the upregulation of the expression of $\mathrm{PC} 1 / 3$.

Inhibition of GLP-1R signaling exacerbates the detrimental effects of palmitate. Treatment with exendin-(9-39) alone, another GLP-1-derived peptide and a GLP-1R antagonist, did not exert any effects on the isolated islets. When combined with exposure to palmitate for $48 \mathrm{~h}$, treatment with exendin-(9-39) resulted in the progressive loss of islet cells that exhibited decreased viability (Fig. 4A) and higher apoptotic levels (Fig. 4B). Furthermore, treatment with exendin-(9-39) exacerbated the detrimental effects of palmitate on $\beta$ cell survival by decreasing PDX1 mRNA (Fig. 4C) $(\mathrm{p}=0.68)$ and protein expression (Fig. 4D). These results suggest that the activation of the intra-islet GLP-1 system ameliorates the detrimental effects of palmitate. 

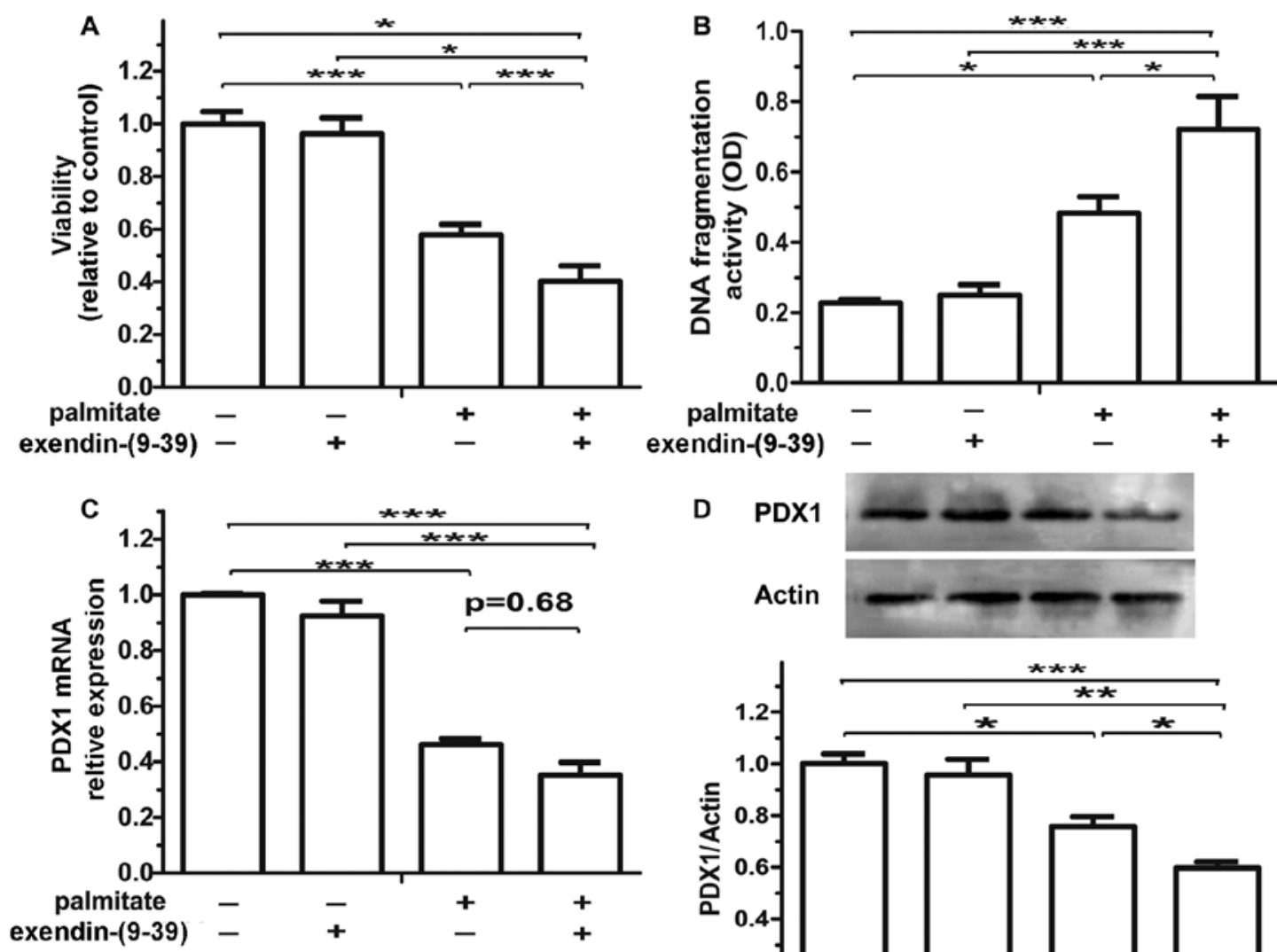

D PDX1
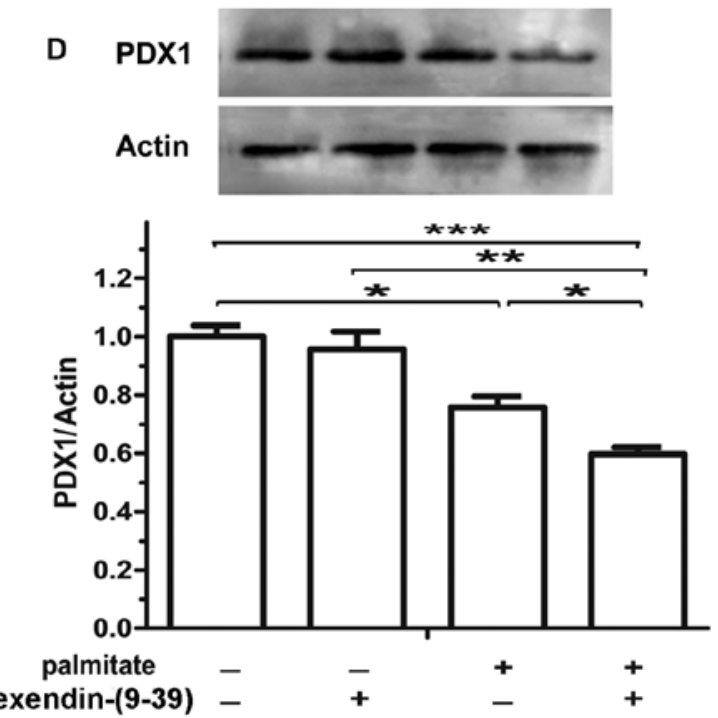

Figure 4. Glucagon-like peptide-1 receptor (GLP-1R) inhibition exacerbates the detrimental effects of palmitate. Isolated islets were pre-treated with the GLP-1R antagonist, exendin-(9-39), $(0.5 \mu \mathrm{mol} / \mathrm{l})$ for $2 \mathrm{~h}$, followed by exposure to $0.5 \mathrm{mmol} / 1$ palmitate for $48 \mathrm{~h}$. Islet (A) viability (detected by MTT assay) and (B) apoptosis (determined by examining histone-associated DNA fragments), and pancreatic duodenal homeobox 1 (PDX1) (C) mRNA (detected by qPCR) and (D) protein levels (detected by immunoblot analysis). $\mathrm{n}=3$ separate islet preparations; ${ }^{*} \mathrm{p}<0.05 ;{ }^{* *} \mathrm{p}<0.01 ;{ }^{* * *} \mathrm{p}<0.001$.

GLP-1R agonist attenuates lipotoxicity-induced islet dysfunction in vitro and in vivo. Considering the short biological half-life of exendin-(9-39) [Kieffer et al (28)], we used the stable, long-lived GLP-1 analog, liraglutide, which is an agonist of GLP-1R. Intriguingly, compared to treatment with palmitate alone, treatment with liraglutide significantly increased islet viability (Fig. 5A) and decreased islet cell apoptosis (Fig. 5B) to levels close to those of the controls. Liraglutide also markedly upregulated PDX1 mRNA expression by 7.70-fold, and this increase was attenuated by treatment with palmitate (Fig. 5C). Moreover, the protective effects of liraglutide were completely abrogated by exendin-(9-39) (Fig. 5A-C). We also investigated the effects of liraglutide on islet function in mice fed a HFD. In the HFD group, liraglutide also increased the mRNA expression of the $\beta$ cell markers, PDX1, Nkx6.1 and glucose transporter 2 (GLUT2) (Fig. 5D). Compared to the mice fed a HFD alone, treatment with liraglutide reduced the plasma insulin concentration (Fig. 5E).

Liraglutide normalizes the islet architecture of mice fed a HFD. Unlike the defined $\alpha$ cell mantle and $\beta$ cell core characteristics of the islets from the mice fed a LFD, the islets from the mice fed a HFD maintained a more scattered organization and a higher percentage of $\alpha$ cells. Furthermore, in the HFD group, there was a greater difference in the expression of insulin (Fig. 6A). As expected, treatment with liraglutide reverted the cell structure to a more normal islet structure (Fig. 6A). Despite the differences in the mean islet areas of the 3 groups (Fig. 6B), the elevated proportions of medium islets $\left(5,000-10,000 \mu \mathrm{m}^{2}\right)$ and large islets $\left(>5,000 \mu \mathrm{m}^{2}\right)$, as well as the mean area of small islets $\left(<5,000 \mu \mathrm{m}^{2}\right)$ that were induced by a HFD were altered by treatment with liraglutide (Table II). In accordance with an elevated $\alpha / \beta$ cell ratio, the HFD group exhibited a significant increase in $\alpha$ cell mass (Fig. 6C and E). Treatment with liraglutide decreased the $\beta$ cell mass (Fig. 6D). However, these results do not completely agree with previously published findings (29), possibly due to the different experimental conditions used, the increased $\beta$ cell proportion and the inhibitory effects of a HFD on insulin expression.

The excess production of ROS induced by palmitate activates the GLP-1 system. Incubation of the cells with $0.5 \mathrm{mmol} / 1$ palmitate for 24,48 or $72 \mathrm{~h}$ markedly increased the intraislet ROS levels by approximately 3.01-, 5.12- and 6.45-fold, respectively (Fig. 7A). In addition, pre-incubation with $5 \mathrm{mmol} / \mathrm{l} \mathrm{NAC}$, neutralized the harmful effects of palmitate, 
Table II. The percentage and mean area $\left(\mu \mathrm{m}^{2}\right)$ of small, medium and large-sized islets per group.

\begin{tabular}{|c|c|c|c|c|c|c|}
\hline & \multicolumn{2}{|r|}{ LFD } & \multicolumn{2}{|r|}{ HFD } & \multicolumn{2}{|c|}{ HFD + liraglutide } \\
\hline & Percentage & Mean area & Percentage & Mean area & Percentage & Mean area \\
\hline $\begin{array}{l}\text { Small islets } \\
\left(<5,000 \mu \mathrm{m}^{2}\right)\end{array}$ & 70.37 & $1470.86 \pm 115.034$ & 54.40 & $2122.65 \pm 154.12^{\mathrm{a}}$ & 66.67 & $2027.76 \pm 148.49^{a}$ \\
\hline $\begin{array}{l}\text { Medium islets } \\
\left(5,000-10,000 \mu \mathrm{m}^{2}\right)\end{array}$ & 15.43 & $7696.40 \pm 256.16$ & 25.82 & $7562.77 \pm 209.21$ & 20.60 & $8101.04 \pm 256.92$ \\
\hline $\begin{array}{l}\text { Large islets } \\
\left(>10,000 \mu \mathrm{m}^{2}\right)\end{array}$ & 14.20 & $26220.00 \pm 3448.25$ & 19.78 & $19460.94 \pm 1306.30$ & 12.73 & $26757.57 \pm 3244.72$ \\
\hline
\end{tabular}

Results are means \pm SEM (n=6-7). ${ }^{a} \mathrm{p}<0.05$ vs. control. LFD, low-fat diet; HFD, high-fat diet.

A

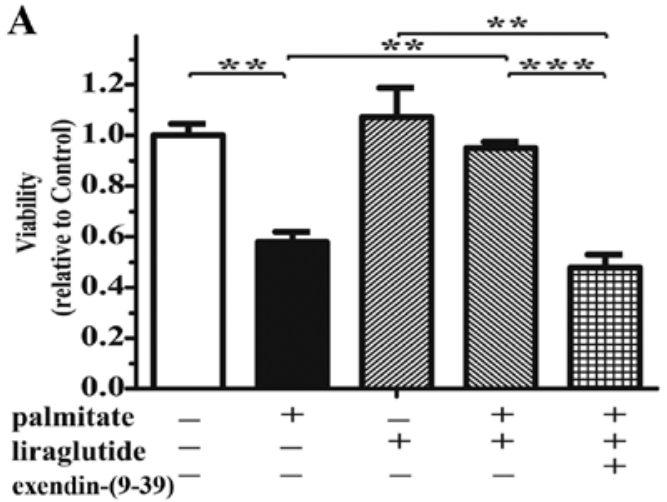

B

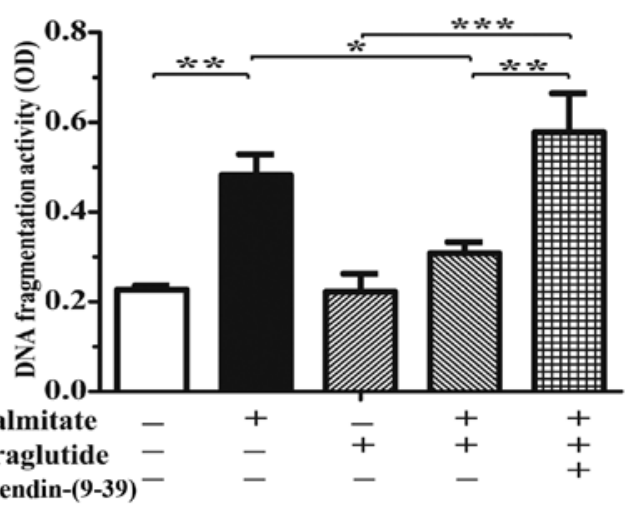

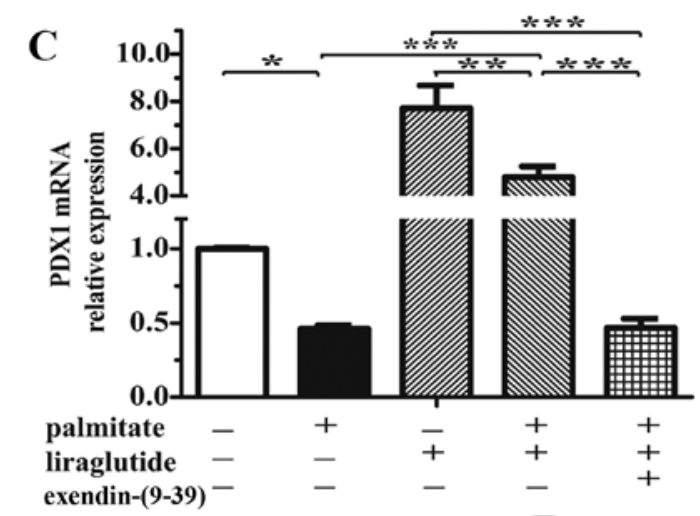

D

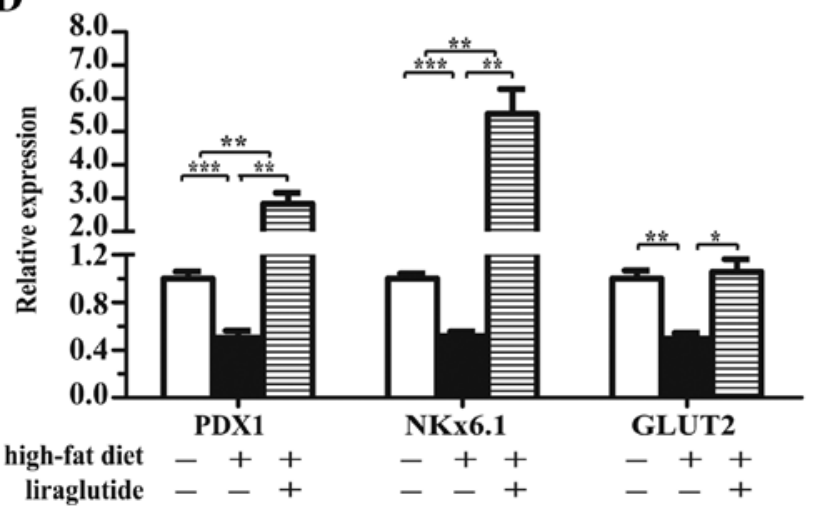

E

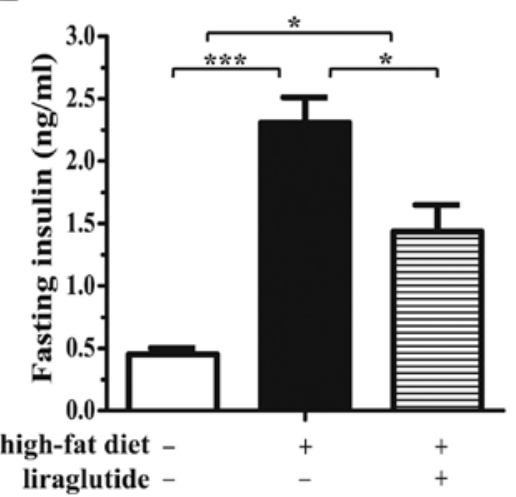

Figure 5. The glucagon-like peptide-1 receptor (GLP-1R) signaling agonist, liraglutide, attenuates lipotoxicity-induced islet dysfunction. Isolated non-diabetic islets were pre-treated with $100 \mathrm{nmol} / 1$ liraglutide and/or $0.5 \mu \mathrm{mol} / 1$ exendin-(9-39) for $2 \mathrm{~h}$, followed by exposure to $0.5 \mathrm{mmol} / 1 \mathrm{palmitate}$ for $48 \mathrm{~h}$. Islet (A) viability (detected by MTT assay) and (B) apoptosis (determined by examining histone-associated DNA fragments), and (C) pancreatic duodenal homeobox 1 (PDX1) mRNA levels (detected by qPCR). $n=3$ separate islet preparations. (D) After 8 weeks on their respective diets, the mRNA expression of PDX1, glucose transporter 2 (GLUT2) and Nkx6.1 was detected in the pancreata of the mice. (E) The plasma insulin levels were detected by insulin enzyme-linked immunosorbent assay (ELISA). $\mathrm{n}=6-7$ mice/group; ${ }^{\mathrm{p}} \mathrm{p}<0.05 ;{ }^{*} \mathrm{p}<0.01 ;{ }^{* * *} \mathrm{p}<0.001$. 
A
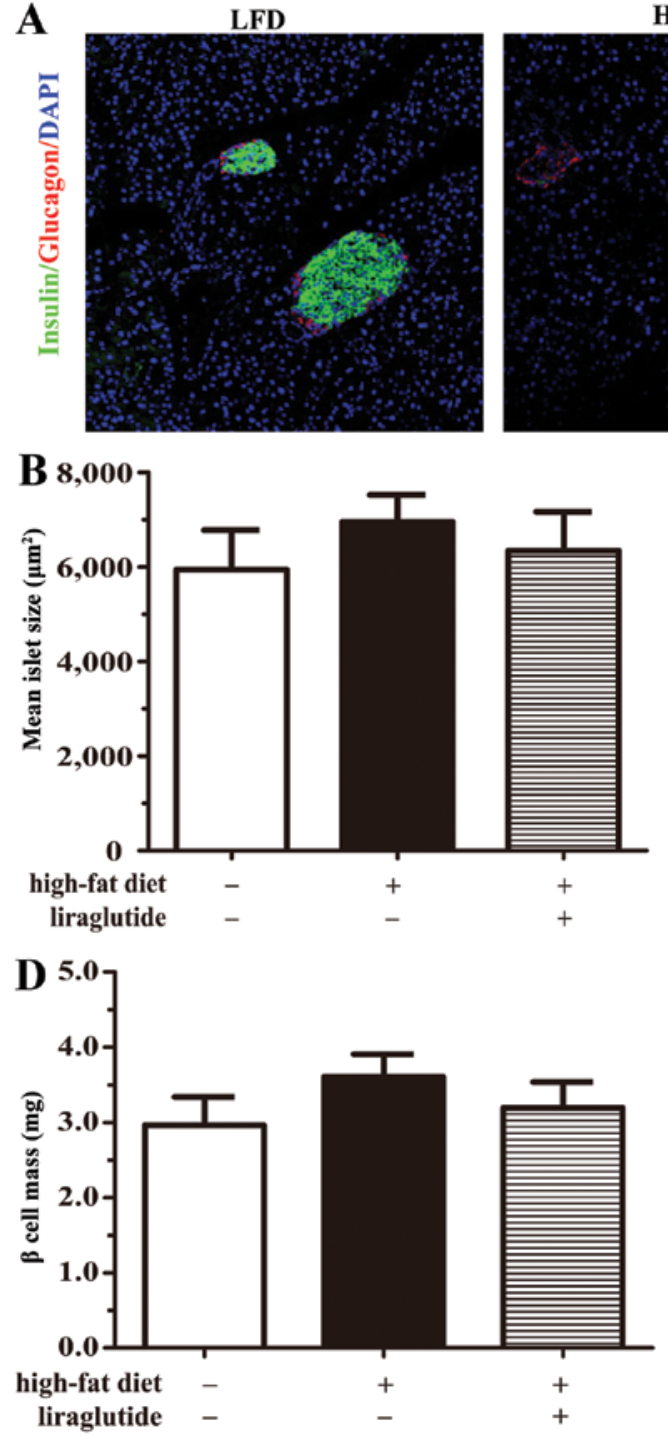

HFD

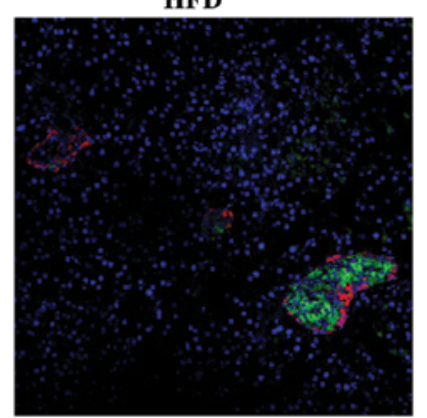

C 40
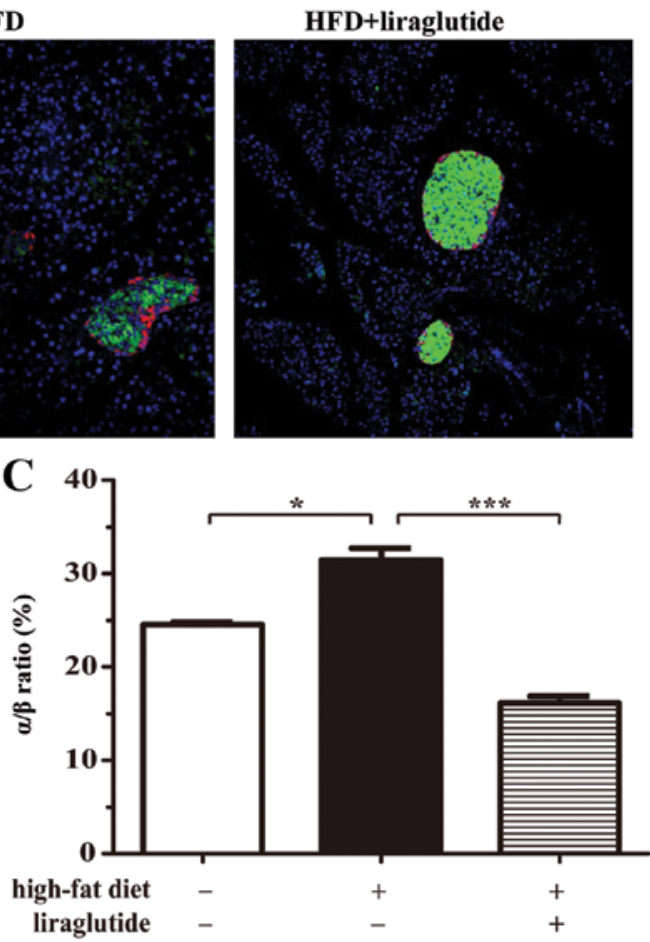

$\mathbf{E}$

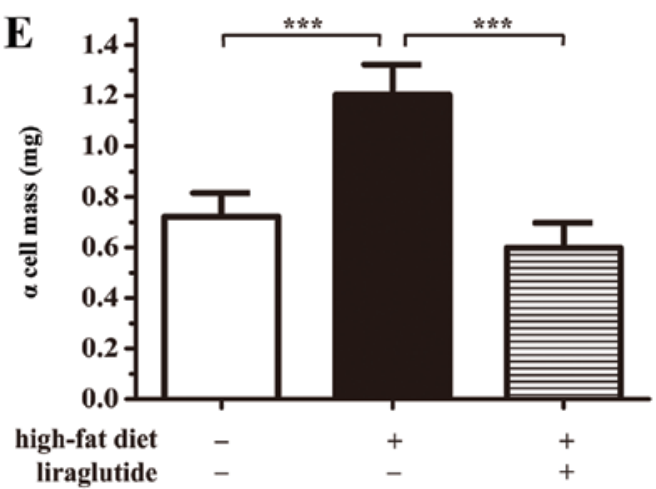

Figure 6. Liraglutide normalizes the islet architecture of mice fed a high-fat diet (HFD). (A) Representative images of staining for insulin (green) and glucagon (red) After immunofluorescence, areas labeled for insulin ( $\beta$-cell) and glucagon (red) were measured, and the results are expressed as the mean (B) islet size, $(\mathrm{C}) \alpha / \beta$ ratio, (D) $\beta$ cell mass and (E) $\alpha$ cell mass. Analyses were performed on histological sections obtained from mice fed a low-fat diet (LFD) + the placebo (phosphate-buffered saline) (LFD; n=6), a HFD + placebo (phosphate-buffered saline) (HFD; n=7) or a HFD + liraglutide $(\mathrm{n}=6) .{ }^{*} \mathrm{p}<0.05 ;{ }^{* * * *} \mathrm{p}<0.001$.

increased islet viability (by 1.43 -fold; Fig. 7B) and decreased apoptosis by approximately $64.84 \%$ (Fig. 7C) in the presence of $0.5 \mathrm{mmol} / 1$ palmitate. Importantly, NAC significantly decreased the PC1/3 mRNA levels (Fig. 7D) and the GLP-1 concentration in the cell lysates (Fig. 7E), which may be due to the attenuation of $\beta$ cell injury. Nonetheless, the elevated levels of PC1/3 mRNA (Fig. 7D) and GLP-1 protein, which were induced by palmitate, did not return to normal after NAC treatment (Fig. 7E), suggesting that the inhibition did not completely reverse the detrimental effects of palmitate overload in the pancreatic islets.

GLP-1R signaling helps to maintain the oxidative balance. Given the intermediary role of oxidative stress in palmitate-induced injury, we hypothesized that GLP-1R signaling may re-shape the oxidative balance by suppressing the generation of ROS and enhancing antioxidant defenses. The inhibition of GLP-1R signaling by exendin-(9-39) (in combi- nation with palmitate) also slightly increased the production of ROS ( $p=0.045$; Fig. 8A). Furthermore, the activation of GLP-1R by liraglutide decreased the ROS levels in the isolated islets ( $\mathrm{p}=0.038$; Fig. 8B). Notably, these changes were directly confirmed by qPCR, which revealed a clear and widespread reshaping of the oxidative balance. Treatment with liraglutide attenuated the palmitate-induced activation of $\mathrm{NAD}(\mathrm{P}) \mathrm{H}$ oxidase components, including NADPH oxidase 4 (NOX4), p22phox and gp91phox (Fig. 8C). Simultaneously, treatment with liraglutide upregulated the expression of mitochondrialspecific superoxide dismutase 2 (SOD2) and glutathione peroxidase 1 (GPx-1) (Fig. 8D).

Liraglutide helps to attenuate islet inflammation. Based on the fact that the nuclear factor $\kappa \mathrm{B}(\mathrm{NF}-\kappa \mathrm{B})$ activation by ROS (30) and inflammation are key to the development of $\beta$ cell failure (31), we examined the effects of liraglutide on inflammatory factors and the $\mathrm{NF}-\kappa \mathrm{B}$ pathway in pancreatic islets. 

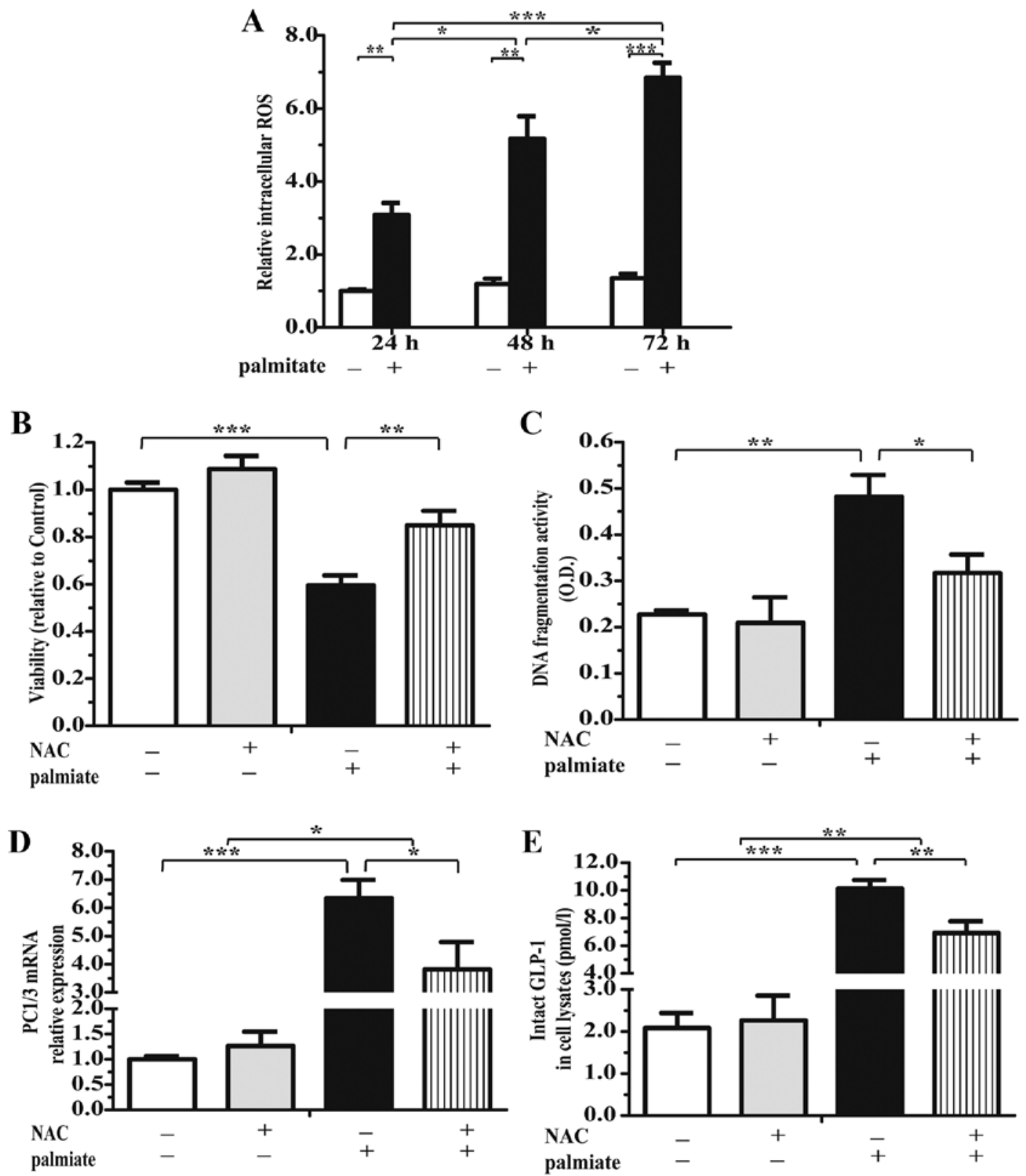

Figure 7. Prolonged exposure to palmitate induces reactive oxygen species (ROS) productin and activates the glucagon-like peptide-1 (GLP-1) system. (A) Following incubation with $0.5 \mathrm{mmol} / 1$ palmitate for the indicated periods of time, ROS levels were detected by DCFH-DA. Following pre-incubation with $5 \mathrm{mmol} / 1 \mathrm{~N}$-acetylcysteine (NAC) for $48 \mathrm{~h}$, cell (B) viability (by MTT assay) and (C) apoptosis (by examining histone-associated DNA fragments), and (D) prohormone convertase 1/3 ( $\mathrm{PC1} / 3$ ) mRNA (by qPCR) and (E) GLP-1 levels (by ELISA) in the cell lysates were determined. $\mathrm{n}=3$ separate isolated islet preparations; ${ }^{*} \mathrm{p}<0.05 ;{ }^{* *} \mathrm{p}<0.01 ;{ }^{* * *} \mathrm{p}<0.001$.

Double immunostaining revealed that the p65 protein expression levels were markedly increased in the pancreatic islets of the mice fed a HFD compared to those of the islets of the mice fed a LFD (Fig. 9A). Furthermore, in the isolated islets, treatment with liraglutide suppressed the palmitate-induced expression of inflammatory factors, including tumor necrosis factor- $\alpha$ (TNF- $\alpha$ ), interleukin (IL)-1 $\beta$ and IL-6 (Fig. 9B).

\section{Discussion}

To the best of our knowledge, the present study for the first time examined the hypothesis that lipotoxicity directly stimulates the generation of immature pro- $\alpha$ cells, resulting in pro- $\alpha$ cells producing endogenous GLP-1 to facilitate $\beta$ cell survival by maintaining the oxidative balance and by inhibiting islet inflammation. Prolonged exposure to palmitate induced lipotoxicity, and a HFD induced $\mathrm{PC} 1 / 3$ expression and, in turn, increased the synthesis and release of GLP-1, which were partly mediated by lipotoxicity-induced oxidative stress. The activation of GLP-1R signaling was attributed to the normalization of islet function and structure. Furthermore, GLP-1 exerted protective effects against lipid overload, partially by increasing antioxidant gene expression and decreasing the levels of ROS, NF- $\mathrm{B}$ and inflammatory factors.

Evidence examining the striking innate plasticity of islets has recently received significant attention as the dedifferentiation of 

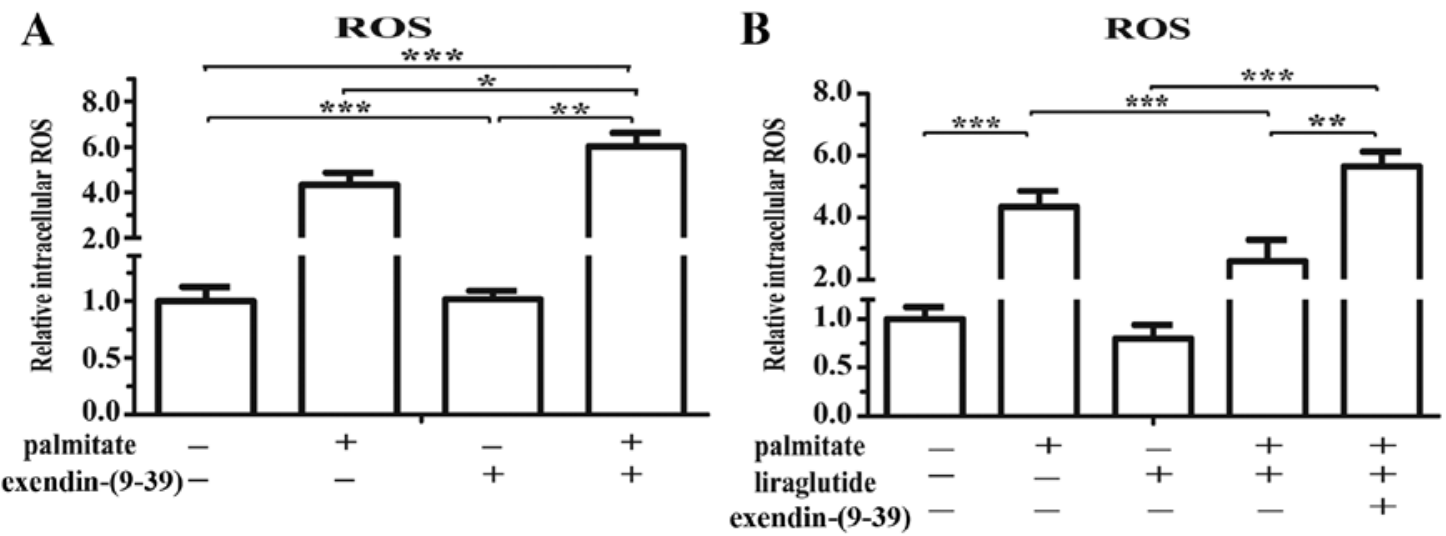

C

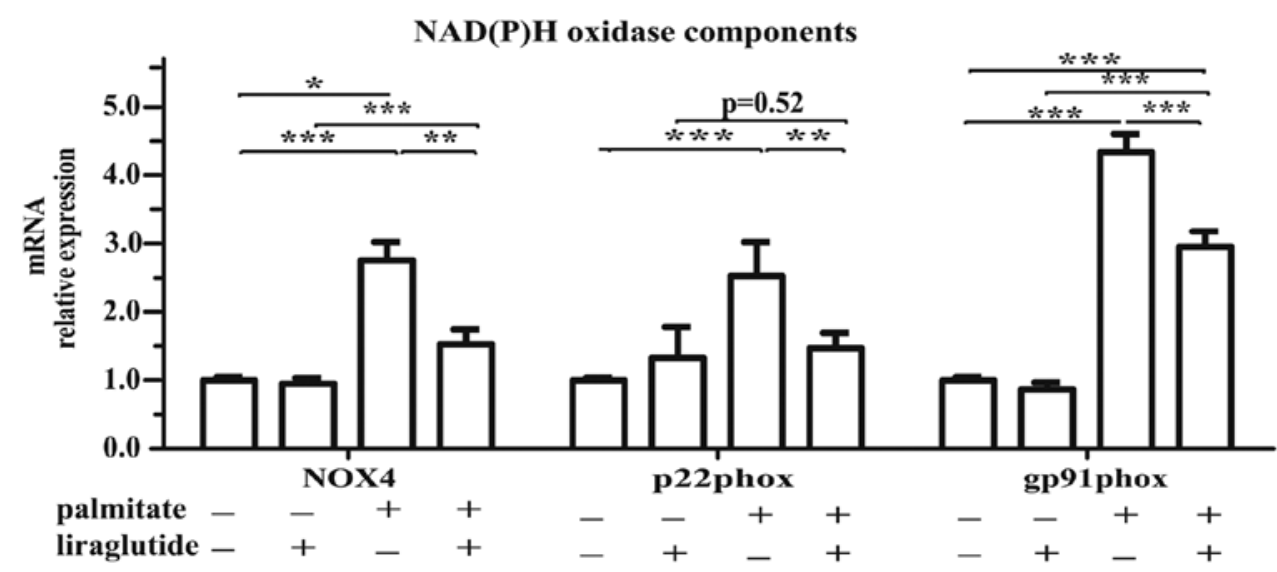

D

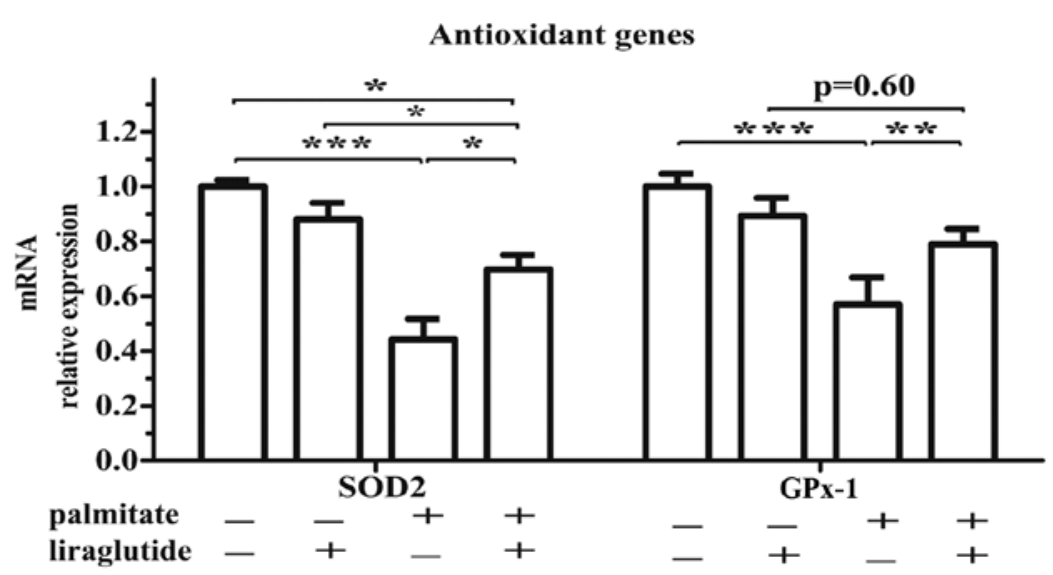

Figure 8. Glucagon-like peptide-1 receptor (GLP-1R) signaling exerts inhibitory effects on the generation of reactive oxygen species (ROS). (A and B) Following pre-incubation with $100 \mathrm{nmol} / 1$ liraglutide and/or $0.5 \mu \mathrm{mol} / 1$ exendin-(9-39) for $2 \mathrm{~h}$, followed by exposure to $0.5 \mathrm{mmol} / 1$ palmitate for $48 \mathrm{~h}$, ROS levels were detected byDCFH-DA, and (C) the mRNA expression of NAD(P)H oxidase components [including NADPH oxidase 4 (NOX4), p22phox and gp91phox], and (D) antioxidant genes [superoxide dismutase 2 (SOD2) and glutathione peroxidase-1 (GPX-1)] was detected by qPCR. n=3 separate isolated islet preparations; ${ }^{*} \mathrm{p}<0.05 ;{ }^{* *} \mathrm{p}<0.01 ;{ }^{* * *} \mathrm{p}<0.001$.

hyperplastic $\alpha$ cells maintains an immature pro- $\alpha$ phenotype in response to $\beta$ cell stress or injury (16). As $\alpha$ cells constitutively express proglucagon, their plasticity is manifested in the expression of glucagon or GLP-1 and depends on the relative levels of PC2 and PC1/3 (16). In models of insulin resistance or diabetes, there is a significant, progressive increase in intra-islet GLP-1 expression based on the upregulation of $\mathrm{PC} 1 / 3$ expression $(32,33)$. The present study similarly demonstrated that lipotoxicity upregulated GLP-1 expression in response to $\beta$ cell injury. Generally, the increase in GLP-1 expression was attributed to pro- $\alpha$ cells, which are derived from the dedifferentiation of hyperplastic $\alpha$ cells. $\beta$ cells may serve as an alternative source of pro- $\alpha$ cells since the dedifferentiation of $\beta$ cells to progenitor-like cells caused by metabolic stress may also represent a distinct 'pro- $\alpha$ ' cell differentiation stage $(34,35)$. Therefore, the identification of a set of pro- $\alpha$ cells that contribute to the endogenous GLP-1 system supports the view that it is advantageous for islet cells to dedifferentiate to facilitate their survival.

Unequivocally, in our study, intra-islet GLP-1 enhanced $\beta$ cell survival against lipotoxicity through a pleiotropic mech- 
A
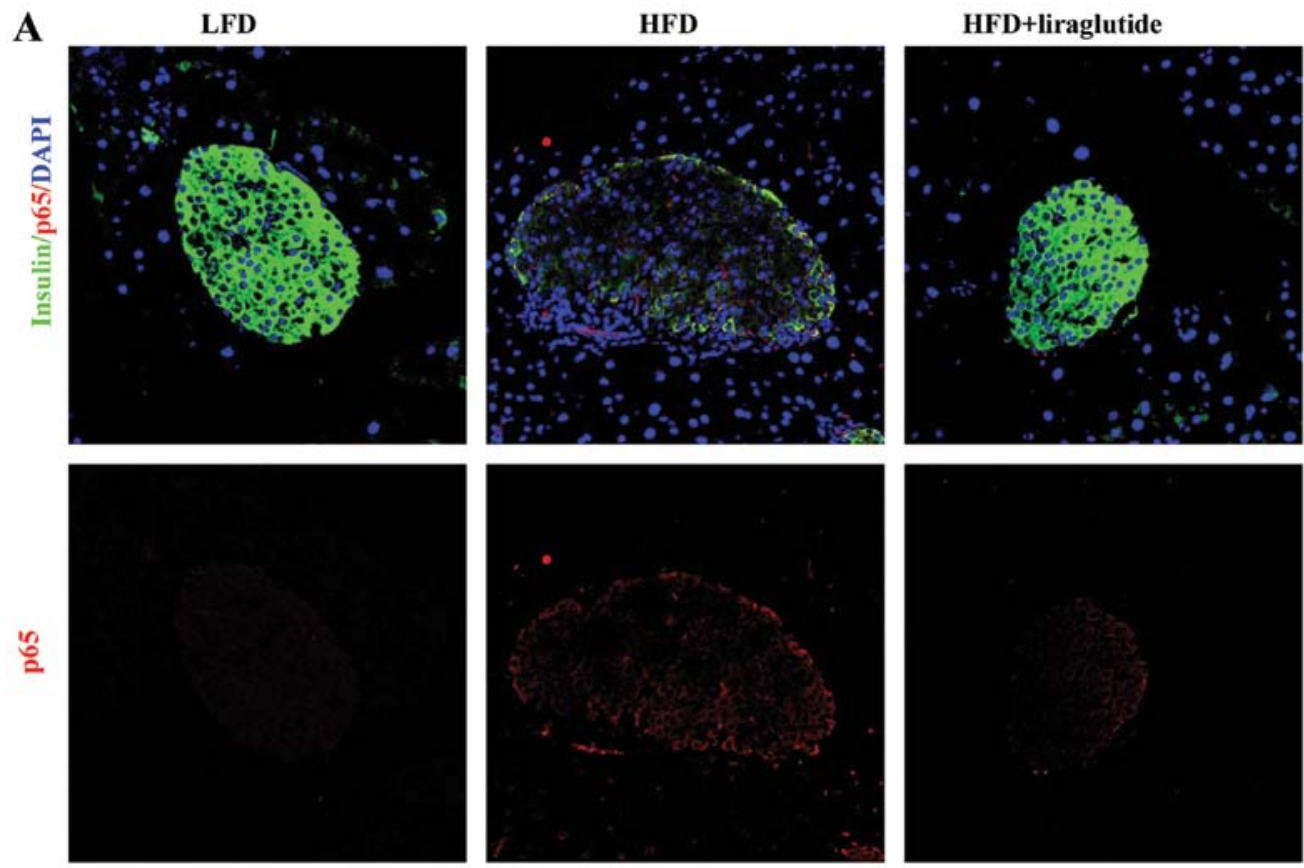

B

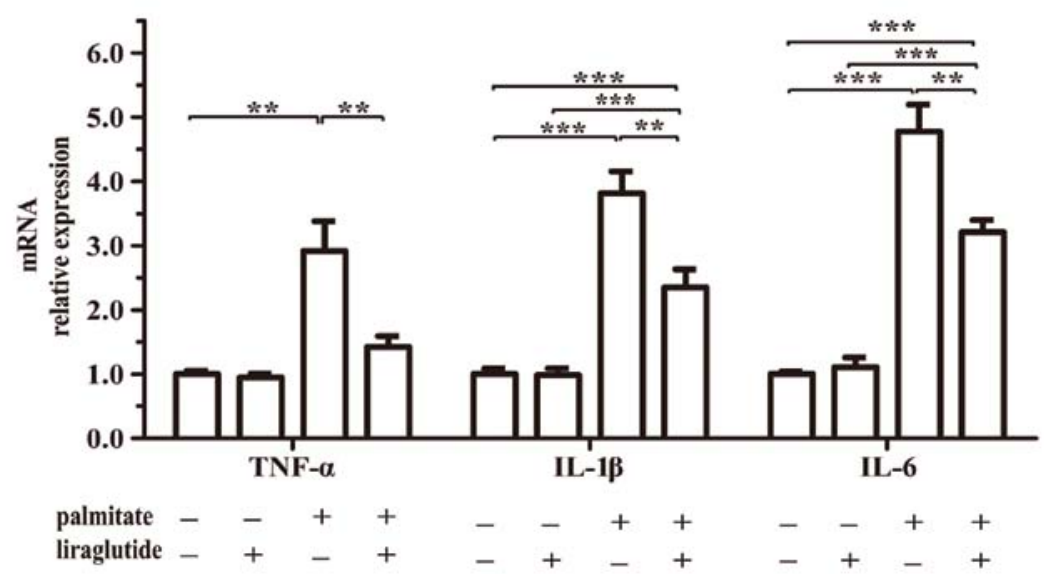

Figure 9. Glucagon-like peptide-1 receptor (GLP-1R) signaling suppresses islet inflammation. (A) Representative images of staining for insulin (green) and p65 (red) in vivo. $\mathrm{n}=6-7$ mice. (B) Following pre-incubation with $100 \mathrm{nmol} / 1$ liraglutide for $2 \mathrm{~h}$, followed by exposure to $0.5 \mathrm{mmol} / \mathrm{l}$ palmitate for $48 \mathrm{~h}$, tumor necrosis factor- $\alpha$ (TNF- $\alpha$ ), interleukin (IL) $-1 \beta$ and IL- 6 mRNA levels were detected by qPCR. $n=3$ separate isolated islet preparations. ${ }^{* * *} \mathrm{p}<0.01 ;{ }^{* * * *} \mathrm{p}<0.001$.

anism. Initially, intra-islet GLP-1/GLP-1R signaling partially decreased the palmitate-induced damage to $\beta$ cells. The GLP-1R antagonist, exendin-(9-39), further suppressed islet viability, increased apoptosis and inhibited PDX1 transcription in the presence of palmitate after $48 \mathrm{~h}$. Additionally, our data demonstrated that GLP-1/GLP-1R signaling attenuated the transcription of $\beta$ cell markers, such as insulin, PDX1, Nkx6.1 and GLUT2. GLP-1R signaling upregulates the insulin gene promoter by inhibiting $\mathrm{p} 38$ mitogen-activated protein kinase (p38 MAPK) (8). The shielding action of GLP-1 also involves the activation of the phosphoinositide 3-kinase (PI3K) and extracellular signal-regulated kinase (ERK) pathways and the upregulation of PDX-1 transcription (36). Finally, GLP-1 normalizes islet structure by promoting proliferation, inhibiting apoptosis and normalizing the distribution of islet cells. GLP-1 protects pancreatic $\beta$ cells against lipotoxicity-induced apoptosis by activating peroxisome proliferator-activated receptor (PPAR) $-\beta / \delta$ (7) and promotes $\beta$ cell proliferation medi- ated through the EGF pathway (5). Therefore, the activation of the endogenous GLP-1 system appears to be a 'self-defense' response in pancreatic islets. However, whether there are other more specific 'protectors' in the prevention and treatment of lipotoxicity remains to be determined.

Our data suggest that oxidative stress plays a role as the bridge between lipid overload and the intra-islet GLP-1 system. Oxidative stress is a common biochemical trigger of stress-sensitive signaling pathways, including NF- $\mathrm{KB}$, p38 MAPK and JNK $(37,38)$. Moreover, $\beta$ cells are particularly susceptible to the damage inflicted by oxidative stress due to low levels of free-radical scavenging enzymes $(37,39)$. Exendin-4, another GLP-1R agonist, protects endothelial cells from palmitate-induced apoptosis by modulating stress-sensitive signaling pathways (40). In a previous study, in rats with tacrolimus-induced diabetes, the dipeptidyl peptidase-4 (DPP4) inhibitor, MK-0626, decreased the levels of 8-OHdG (a marker of oxidative DNA damage) and increased the levels of manga- 
nese superoxide dismutase and heme oxygenase-1 (41). In rats with streptozotocin-induced diabetes, liraglutide was shown to directly protect the rats against oxidative stress through the inhibition of $\mathrm{NAD}(\mathrm{P}) \mathrm{H}$ oxidases (11). Consistent with our results, Lotfy et al (9) reported that another GLP-1R signaling agonist, exenatide, elevated the expression of catalase and glutathione reductase in the pancreata of diabetic rats. Small GLP-1-derived peptides also modulate nutrient homeostasis by suppressing oxidative stress $(42,43)$. In addition, ROS activate NF- $\kappa \mathrm{B}$ and induce the generation of inflammatory factors, and our data, as well as previous findings demonstrate that liraglutide decreases p65 expression and the expression of inflammatory factors, such as TNF- $\alpha$ and IL-1 $\beta$ (30).

In conclusion, the findings of the present study suggest that endogenous GLP-1/GLP-1R signaling is a 'self-defense' pathway that facilitates islet survival against lipotoxicity. The protective mechanism of intra-islet GLP-1 may be the achievement of oxidative balance, as well as the inhibition of islet inflammation. Further research on the intra-islet GLP-1 system is required to obtain a better understanding of the mechanisms through which adult $\beta$ cells maintain or change their identity due to lipotoxicity.

\section{Acknowledgements}

The present study was supported by a grant provided by the National Natural Science Foundation of China (no. 81370880).

\section{References}

1. Kusminski CM, Shetty S, Orci L, Unger RH and Scherer PE: Diabetes and apoptosis: Lipotoxicity. Apoptosis 14: 1484-1495, 2009.

2. Kim JW and Yoon KH: Glucolipotoxicity in pancreatic $\beta$-cells. Diabetes Metab J 35: 444-450, 2011.

3. Rial E, Rodríguez-Sánchez L, Gallardo-Vara E, Zaragoza P, Moyano E and González-Barroso MM: Lipotoxicity, fatty acid uncoupling and mitochondrial carrier function. Biochim Biophys Acta 1797: 800-806, 2010.

4. Kim W and Egan JM: The role of incretins in glucose homeostasis and diabetes treatment. Pharmacol Rev 60: 470-512, 2008

5. Buteau J: GLP-1 receptor signaling: Effects on pancreatic beta-cell proliferation and survival. Diabetes Metab 34 (Suppl 2): S73-S77, 2008.

6. Lamont BJ and Andrikopoulos S: Hope and fear for new classes of type 2 diabetes drugs: Is there preclinical evidence that incretinbased therapies alter pancreatic morphology? J Endocrinol 221: T43-T61, 2014.

7. Yang Y, Tong Y, Gong M, Lu Y, Wang C, Zhou M, Yang Q, Mao T and Tong N: Activation of PPAR $\beta / \delta$ protects pancreatic $\beta$ cells from palmitate-induced apoptosis by upregulating the expression of GLP-1 receptor. Cell Signal 26: 268-278, 2014.

8. Kemp DM and Habener JF: Insulinotropic hormone glucagon-like peptide-1 (GLP-1) activation of insulin gene promoter inhibited by p38 mitogen-activated protein kinase. Endocrinology 142: $1179-1187,2001$.

9. Lotfy M, Singh J, Rashed H, Tariq S, Zilahi E and Adeghate E: Mechanism of the beneficial and protective effects of exenatide in diabetic rats. J Endocrinol 220: 291-304, 2014

10. Chen LN, Lyu J, Yang XF, Ji WJ, Yuan BX, Chen MX, Ma X and Wang B: Liraglutide ameliorates glycometabolism and insulin resistance through the upregulation of GLUT4 in diabetic KKAy mice. Int J Mol Med 32: 892-900, 2013.

11. Hendarto H, Inoguchi T, Maeda Y, Ikeda N, Zheng J, Takei R, Yokomizo H, Hirata E, Sonoda N and Takayanagi R: GLP-1 analog liraglutide protects against oxidative stress and albuminuria in streptozotocin-induced diabetic rats via protein kinase A-mediated inhibition of renal $\mathrm{NAD}(\mathrm{P}) \mathrm{H}$ oxidases. Metabolism 61: 1422-1434, 2012.
12. Liu Z, Stanojevic V, Avadhani S, Yano T and Habener JF: Stromal cell-derived factor-1 (SDF-1)/chemokine (C-X-C motif) receptor 4 (CXCR4) axis activation induces intra-islet glucagonlike peptide-1 (GLP-1) production and enhances beta cell survival. Diabetologia 54: 2067-2076, 2011.

13. Pugazhenthi U, Velmurugan K, Tran A, Mahaffey G and Pugazhenthi S: Anti-inflammatory action of exendin-4 in human islets is enhanced by phosphodiesterase inhibitors: Potential therapeutic benefits in diabetic patients. Diabetologia 53: 2357-2368, 2010.

14. Marchetti P, Lupi R, Bugliani M, Kirkpatrick CL, Sebastiani G, Grieco FA, Del Guerra S, D'Aleo V, Piro S, Marselli L, et al: A local glucagon-like peptide 1 (GLP-1) system in human pancreatic islets. Diabetologia 55: 3262-3272, 2012.

15. Habener JF and Stanojevic V: Alpha cells come of age. Trends Endocrinol Metab 24: 153-163, 2013.

16. Habener JF and Stanojevic V: $\alpha$-cell role in $\beta$-cell generation and regeneration. Islets 4: 188-198, 2012.

17. Nie Y, Nakashima M, Brubaker PL, Li QL, Perfetti R, Jansen E, Zambre Y, Pipeleers D and Friedman TC: Regulation of pancreatic $\mathrm{PC} 1$ and $\mathrm{PC} 2$ associated with increased glucagon-like peptide 1 in diabetic rats. J Clin Invest 105: 955-965, 2000.

18. Zhang Y, Zhang Y, Bone RN, Cui W, Peng JB, Siegal GP, Wang $\mathrm{H}$ and $\mathrm{Wu} \mathrm{H}$ : Regeneration of pancreatic non- $\beta$ endocrine cells in adult mice following a single diabetes-inducing dose of streptozotocin. PLoS One 7: e36675, 2012.

19. Yano T, Liu Z, Donovan J, Thomas MK and Habener JF: Stromal cell derived factor-1 (SDF-1)/CXCL12 attenuates diabetes in mice and promotes pancreatic beta-cell survival by activation of the prosurvival kinase Akt. Diabetes 56: 2946-2957, 2007.

20. Thyssen S, Arany E and Hill DJ: Ontogeny of regeneration of beta-cells in the neonatal rat after treatment with streptozotocin. Endocrinology 147: 2346-2356, 2006.

21. Lau T, Carlsson PO and Leung PS: Evidence for a local angiotensin-generating system and dose-dependent inhibition of glucose-stimulated insulin release by angiotensin II in isolated pancreatic islets. Diabetologia 47: 240-248, 2004.

22. Wang HW, Mizuta M, Saitoh Y, Noma K, Ueno H and Nakazato M: Glucagon-like peptide-1 and candesartan additively improve glucolipotoxicity in pancreatic $\beta$-cells. Metabolism 60: 1081-1089, 2011.

23. Jaksch $\mathrm{C}$ and Thams P: A critical role for CK2 in cytokineinduced activation of $\mathrm{NF \kappa B}$ in pancreatic $\beta$ cell death. Endocrine 47: 117-128, 2014.

24. Yuan L, Lu CL, Wang Y, Li Y and Li XY: Ang (1-7) protects islet endothelial cells from palmitate-induced apoptosis by AKT, eNOS, p38 MAPK, and JNK pathways. J Diabetes Res 2014: 391476, 2014

25. Fraulob JC, Ogg-Diamantino R, Fernandes-Santos C, Aguila MB and Mandarim-de-Lacerda CA: A mouse model of metabolic syndrome: Insulin resistance, fatty liver and non-alcoholic fatty pancreas disease (NAFPD) in C57BL/6 mice fed a high fat diet. J Clin Biochem Nutr 46: 212-223, 2010.

26. Davidson HW: (Pro)Insulin processing: A historical perspective. Cell Biochem Biophys 40 (Suppl 3): 143-158, 2004.

27. Portela-Gomes GM, Grimelius L and Stridsberg M: Prohormone convertases 1/3, 2, furin and protein 7B2 (Secretogranin V) in endocrine cells of the human pancreas. Regul Pept 146: 117-124, 2008.

28. Kieffer TJ, McIntosh CH and Pederson RA: Degradation of glucose-dependent insulinotropic polypeptide and truncated glucagon-like peptide 1 in vitro and in vivo by dipeptidyl peptidase IV. Endocrinology 136: 3585-3596, 1995.

29. Mondragon A, Davidsson D, Kyriakoudi S, Bertling A, Gomes-Faria R, Cohen P, Rothery S, Chabosseau P, Rutter GA and da Silva Xavier G: Divergent effects of liraglutide, exendin-4, and sitagliptin on beta-cell mass and indicators of pancreatitis in a mouse model of hyperglycaemia. PLoS One 9: e104873, 2014.

30. Gloire G, Legrand-Poels S and Piette J: NF-kappaB activation by reactive oxygen species: Fifteen years later. Biochem Pharmacol 72: 1493-1505, 2006.

31. Quan W, Jo EK and Lee MS: Role of pancreatic $\beta$-cell death and inflammation in diabetes. Diabetes Obes Metab 15 (Suppl 3): 141-151, 2013.

32. O'Malley TJ, Fava GE, Zhang Y, Fonseca VA and Wu H: Progressive change of intra-islet GLP-1 production during diabetes development. Diabetes Metab Res Rev 30: 661-668, 2014. 
33. Hansen AM, Bödvarsdottir TB, Nordestgaard DN, Heller RS, Gotfredsen CF, Maedler K, Fels JJ, Holst JJ and Karlsen AE: Upregulation of alpha cell glucagon-like peptide 1 (GLP-1) in Psammomys obesus - an adaptive response to hyperglycaemia? Diabetologia 54: 1379-1387, 2011.

34. Talchai C, Xuan S, Lin HV, Sussel L and Accili D: Pancreatic $\beta$ cell dedifferentiation as a mechanism of diabetic $\beta$ cell failure. Cell 150: 1223-1234, 2012.

35. Wang Z, York NW, Nichols CG and Remedi MS: Pancreatic $\beta$ cell dedifferentiation in diabetes and redifferentiation following insulin therapy. Cell Metab 19: 872-882, 2014.

36. Tortosa $F$ and Dotta F: Incretin hormones and beta-cell mass expansion: What we know and what is missing? Arch Physiol Biochem 119: 161-169, 2013.

37. Evans JL, Goldfine ID, Maddux BA and Grodsky GM: Oxidative stress and stress-activated signaling pathways: A unifying hypothesis of type 2 diabetes. Endocr Rev 23: 599-622, 2002.

38. Yuzefovych LV, LeDoux SP, Wilson GL and Rachek LI: Mitochondrial DNA damage via augmented oxidative stress regulates endoplasmic reticulum stress and autophagy: Crosstalk, links and signaling. PLoS One 8: e83349, 2013.
39. Gehrmann W, Elsner M and Lenzen S: Role of metabolically generated reactive oxygen species for lipotoxicity in pancreatic $\beta$-cells. Diabetes Obes Metab 12 (Suppl 2): 149-158, 2010

40. Erdogdu O, Eriksson L, Xu H, Sjöholm A, Zhang Q and Nyström T: Exendin-4 protects endothelial cells from lipoapoptosis by PKA, PI3K, eNOS, p38 MAPK, and JNK pathways. J Mol Endocrinol 50: 229-241, 2013.

41. Jin L, Lim SW, Doh KC, Piao SG, Jin J, Heo SB, Chung BH and Yang CW: Dipeptidyl peptidase IV inhibitor MK-0626 attenuates pancreatic islet injury in tacrolimus-induced diabetic rats. PLoS One 9: e100798, 2014

42. Tomas E, Stanojevic V and Habener JF: GLP-1-derived nonapeptide GLP-1(28-36)amide targets to mitochondria and suppresses glucose production and oxidative stress in isolated mouse hepatocytes. Regul Pept 167: 177-184, 2011.

43. Liu Z,Stanojevic V,BrindamourLJ and HabenerJF: GLP1-derived nonapeptide GLP1(28-36)amide protects pancreatic $\beta$-cells from glucolipotoxicity. J Endocrinol 213: 143-154, 2012. 